\title{
The CALHM1 P86L Polymorphism is a Genetic Modifier of Age at Onset in Alzheimer's Disease: a Meta-Analysis Study
}

Jean-Charles Lambert ${ }^{\mathrm{a}, \mathrm{b}, \mathrm{c}, *}$, Kristel Sleegers ${ }^{\mathrm{d}, \mathrm{e}}$, Antonio González-Pérez ${ }^{\mathrm{f}}$, Martin Ingelsson ${ }^{\mathrm{g}}$, Gary W. Beecham ${ }^{\mathrm{h}}$, Mikko Hiltunen ${ }^{\mathrm{i}}$, Onofre Combarros $^{\mathrm{j}}$, Maria J. Bullido ${ }^{\mathrm{k}}$, Nathalie Brouwers ${ }^{\mathrm{d}, \mathrm{e}}$, Karolien Bettens ${ }^{\mathrm{d}, \mathrm{e}}$, Claudine Berrl ${ }^{\mathrm{l}}$, Florence Pasquier ${ }^{\mathrm{c}, \mathrm{m}}$, Florence Richard ${ }^{\mathrm{a}, \mathrm{b}, \mathrm{c}, \mathrm{m}}$, Steven T. DeKosky ${ }^{\mathrm{n}}$, Didier Hannequin $^{\mathrm{o}}$, Jonathan L. Haines ${ }^{\mathrm{p}}$, Gloria Tognoni ${ }^{\mathrm{q}}$, Nathalie Fiévet ${ }^{\mathrm{a}}{ }^{\mathrm{b}}$, Jean-François Dartigues ${ }^{\mathrm{r}}$, Christophe Tzourio ${ }^{\mathrm{s}, \mathrm{t}}$, Sebastiaan Engelborghs ${ }^{\mathrm{e}, \mathrm{u}}$, Beatrice Arosio $^{\mathrm{v}}$, Elicer Coto ${ }^{\mathrm{w}}$, Peter De Deyn ${ }^{\mathrm{e}, \mathrm{u}}$, Maria Del Zompo ${ }^{\mathrm{x}}$, Ignacio Mateo ${ }^{\mathrm{j}}$, Merce Boada $^{\mathrm{y}, \mathrm{z}}$, Carmen Antunez ${ }^{\mathrm{aa}, \mathrm{bb}}$, Jesus Lopez-Arrieta ${ }^{\mathrm{cc}}$, Jacques Epelbaum $^{\text {dd }}$, Brit-Maren Michaud Schjeide ${ }^{\mathrm{ee}}$, Ana Frank-Garciaff ${ }^{\mathrm{ff}}$, Vilmentas Giedraitis ${ }^{\mathrm{g}}$, Seppo Helisalmi ${ }^{j}$, Elisa Porcellinigg ${ }^{\text {, Alberto Pilotto }}{ }^{\text {hh }}$, Paola Fortii ${ }^{i}$, Raffaele Ferrij ${ }^{j j}$, Marc Delepine ${ }^{k k}$, Diana Zelenika ${ }^{\mathrm{kk}}$, Mark Lathrop ${ }^{\mathrm{kk}, 1 \mathrm{ll}}$, Elio Scarpini ${ }^{\mathrm{mm}}$, Gabriele Siciliano ${ }^{\mathrm{q}}$, Vincenzo Solfrizzi ${ }^{\mathrm{nn}}$, Sandro Sorbi ${ }^{\mathrm{oo}}$, Gianfranco Spalletta ${ }^{\mathrm{pp}}$, Giovanni Ravaglia ${ }^{\mathrm{ii}}$, Fernando Valdivieso ${ }^{\mathrm{k}}$, Saila Vepsäläinen ${ }^{\mathrm{g}}$, Victoria Alvarez ${ }^{\mathrm{w}}$, Paolo Bosco ${ }^{\mathrm{jj}}$, Michelangelo Mancuso ${ }^{\mathrm{q}}$, Francesco Panza ${ }^{\mathrm{nn}}$, Benedetta Nacmias ${ }^{\mathrm{oo}}$, Paola Bossù $^{\mathrm{pp}}$, Olivier Hanon ${ }^{\mathrm{dd}}$, Paola Piccardi ${ }^{\mathrm{x}}$, Giorgio Annoni ${ }^{\mathrm{qq}}$, David Mann ${ }^{\mathrm{rr}}$,

Philippe Marambaud $^{\text {ss,tt }}$, Davide Seripa ${ }^{\text {hh }}$, Daniela Galimberti ${ }^{\mathrm{mm}}$, Rudolph E Tanzi ${ }^{\text {uu }}$, Lars Bertram ${ }^{\text {ee }}$, Corinne Lendon ${ }^{\mathrm{vv}}$, Lars Lannfelt ${ }^{\mathrm{g}}$, Federico Licastro ${ }^{\mathrm{gg}}$, Dominique Campion ${ }^{\mathrm{o}}$,

Margaret A. Pericak-Vance ${ }^{\mathrm{h}}$, Hilkka Soininen ${ }^{\mathrm{i}}$, Christine Van Broeckhoven ${ }^{\mathrm{e}, \mathrm{d}}$, Annick Alpérovitch ${ }^{\mathrm{s}, \mathrm{t}}$, Agustin Ruiz ${ }^{\mathrm{f}}$ M. Ilyas Kamboh ${ }^{\mathrm{ww}}$ and Philippe Amouyel ${ }^{\mathrm{a}, \mathrm{b}, \mathrm{c}, \mathrm{m}}$

a INSERM U744, Lille, France

${ }^{\mathrm{b}}$ Institut Pasteur de Lille, Lille, France

${ }^{\mathrm{c}}$ Université de Lille Nord de France, Lille, France

${ }^{\mathrm{d}}$ Neurodegenerative Brain Diseases group, Department of Molecular Genetics, VIB, Antwerp, Belgium

${ }^{\mathrm{e}}$ Institute Born-Bunge and University of Antwerp, Antwerp, Belgium

${ }_{\mathrm{f}}^{\mathrm{f}}$ Department of Structural Genomics. Neocodex, Sevilla, Spain

${ }^{\mathrm{g}}$ Uppsala University, Stockholm, Sweden

${ }^{\mathrm{h}}$ John P. Hussman Institute for Human Genomics, University of Miami, Miller School of Medicine, Miami, FL, USA

${ }^{\mathrm{i}}$ Department of Neurology, Kuopio University and University Hospital, Kuopio, Finland

${ }^{\mathrm{j}}$ Neurology Service and CIBERNED, "Marqués de Valdecilla" University Hospital (University of Cantabria), Santander, Spain

${ }^{\mathrm{k} C e n t r o ~ d e ~ B i o l o g i a ~ M o l e c u l a r ~ S e v e r o ~ O c h o a ~(U A M-C S I C) ~ a n d ~ C I B E R N E D, ~ U n i v e r s i d a d ~ A u t o n o m a, ~}$ Cantoblanco, Madrid, Spain

${ }^{1}$ INSERM U888, Hôpital La Colombière, Montpellier, France

${ }^{\mathrm{m}} \mathrm{CHRU}$ de Lille, Lille, France

${ }^{\mathrm{n}}$ University of Virginia School of medicine, Charlottesville, VA, USA

${ }^{\circ}$ INSERM U614, Faculté de Médecine-Pharmacie de Rouen, Rouen, France

${ }^{\mathrm{P}}$ Vanderbilt Center for Human Genetics Research, Vanderbilt University Medical Center, Nashville, TN, USA

${ }^{\mathrm{q}}$ Department of Neuroscience, Neurological Clinic, University of Pisa, Pisa, Italy

${ }^{\mathrm{r}}$ INSERM U897, Victor Segalen University, Bordeaux, France

${ }^{\mathrm{s}}$ INSERM U708, Paris, France

${ }^{\mathrm{t}}$ UPMC Univ. Paris 06, Paris, France 
${ }^{\mathrm{u}}$ Memory Clinic and Department of Neurology, ZNA Middelheim, Antwerpen, Belgium

${ }^{v}$ Department of Internal Medicine, Fondazione Policlinico IRCCS, Milan, Italy

${ }^{\mathrm{w}}$ Genetic Molecular Unit, Hospital Universitario Central de Asturias, Oviedo, Spain

${ }^{x}$ Section of Clinical Pharmacology, Department of Neuroscience, University of Cagliari, Cagliari, Italy

${ }^{\mathrm{y}}$ Memory Clinic of Fundació ACE, Institut Català de Neurociències Aplicades, Barcelona, Spain

${ }^{\mathrm{z}}$ Neurology Department, Hospital G. Universitari Vall d'Hebron, Barcelona, Spain

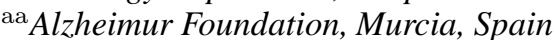

${ }^{\mathrm{bb}}$ Dementia Unit. University Hospital Virgen de la Arrixaca, Murcia, Spain

${ }^{\mathrm{cc}}$ Memory Unit. University Hospital La Paz-Cantoblanco, Madrid, Spain

${ }^{\mathrm{dd}}$ UMR 894, INSERM Faculté de Médecine, Université Paris Descartes, Paris, France

${ }^{\mathrm{ee}}$ Neuropsychiatric Genetics Group, Department of Vertebrate Genomics, Max-Planck Institute for Molecular Genetics, Berlin, Germany

${ }^{\mathrm{ff}}$ Servicio de Neurologia, Hospital Universitario La Paz (UAM) and CIBERNED, Madrid, Spain

gg Department of Experimental Pathology, School of Medicine, University of Bologna, Bologna, Italy

${ }^{\mathrm{hh}}$ Geriatric Unit \& Gerontology-Geriatric Research Laboratory, Department of Medical Science, IRCCS Casa Sollievo della Sofferenza, San Giovanni Rotondo, Italy

${ }^{\mathrm{ii}}$ Department of Internal Medicine Cardiology and Hepatology, University Hospital S. Orsola-Malpighi, Bologna, Italy

${ }^{\mathrm{j}}$ IRCCS Oasi Maria SS, Troina, Italy

${ }^{\mathrm{kk}}$ Centre National de Genotypage, Institut Genomique, Commissariat à l'Énergie Atomique, Evry, France

${ }^{1 l}$ Fondation Jean Dausset-CEPH, Paris, France

${ }^{\mathrm{mm}}$ Department of Neurological Sciences, Dino Ferrari Center, University of Milan, IRCCS Ospedale Maggiore Policlinico, Milan, Italy

${ }^{\mathrm{nn}}$ Department of Geriatrics, Centre for Aging Brain, Memory Unit, University of Bari, Policlinico, Bari, Italy

${ }^{\circ}$ Department of Neurological and Psychiatric Sciences, Florence, Italy

pp Department of Clinical and Behavioral Neurology, IRCCS Santa Lucia Foundation, Roma, Italy

${ }^{\mathrm{qq}}$ Department of Clinical Medicine and Prevention, University of Milano-Bicocca, Monza, Italy

${ }^{\mathrm{rr}}$ Greater Manchester Neuroscience Centre, University of Manchester, Manchester, UK

${ }^{\mathrm{ss}}$ Litwin-Zucker Research Center for the Study of Alzheimer's Disease, Feinstein Institute for Medical Research, North Shore-LIJ, Manhasset, NY, USA

${ }^{\mathrm{tt}}$ Department of Pathology, Albert Einstein College of Medicine, Bronx, NY, USA

${ }^{\mathrm{uu}}$ Genetics and Aging Research Unit, Massachusetts General Hospital, Charlestown, MA, USA

${ }^{\mathrm{v}}$ Molecular Psychiatry Laboratory, Queensland Institute of Medical Research, PO Royal Brisbane Hospital, Queensland, Australia

${ }^{w w}$ Department of Human Genetics and Alzheimer's Disease Research Centre, University of Pittsburgh, Pittsburgh, $P A, U S A$

Accepted 13 June 2010

Abstract. The only established genetic determinant of non-Mendelian forms of Alzheimer's disease (AD) is the $\varepsilon 4$ allele of the apolipoprotein E gene $(A P O E)$. Recently, it has been reported that the P86L polymorphism of the calcium homeostasis modulator 1 gene $(C A L H M 1)$ is associated with the risk of developing $\mathrm{AD}$. In order to independently assess this association, we performed a meta-analysis of 7,873 AD cases and 13,274 controls of Caucasian origin (from a total of 24 centers in Belgium, Finland, France, Italy, Spain, Sweden, the UK, and the USA). Our results indicate that the CALHM1 P86L polymorphism is likely not a genetic determinant of $\mathrm{AD}$ but may modulate age of onset by interacting with the effect of the $\varepsilon 4$ allele of the APOE gene.

Keywords: Age at onset, Alzheimer's disease, apolipoprotein E, CALHM1, polymorphism

Supplementary data available online: http://www.j-alz.com/issues/22/vol22-1.html\#supplementarydata04

\footnotetext{
* Correspondence to: Jean-Charles Lambert, Unité INSERM 744, Institut Pasteur de Lille BP 245,1, rue du professeur Calmette, F59019 Lille cedex, France. Tel.: +33 (0)3 208773 91; Fax: +33 (0)3 208778 94; E-mail: jean-charles.lambert@pasteur-lille.fr.
} 


\section{INTRODUCTION}

Although Alzheimer's disease (AD) is the most common cause of dementia in the elderly, its etiology is still not fully understood. The characterization of causative factors is thus important for better defining the pathophysiological processes involved. Hereditary, earlyonset forms of AD have been linked to disease-causing mutations in three different genes: the amyloid- $\beta$ protein precursor $(A \beta P P)$ gene on chromosome 21 , the presenilin 1 (PSEN1) gene on chromosome 14, and the presenilin 2 (PSEN2) gene on chromosome 1 [1]. However, the known mutations in these three genes account for less than $1 \%$ of all AD cases [2]. Most forms of $\mathrm{AD}$ develop after the age of 65 and are considered to be sporadic because they lack an obvious familial aggregation. The term "sporadic" has, however, been gradually replaced by the concept of non-Mendelian (i.e., genetically complex) transmission. Although the importance of the genetic component of these non-Mendelian forms has long been debated, there is now a large body of evidence suggesting that genetic variation plays the major role in determining risk for this form of $\mathrm{AD}$ as well. This evidence is largely based on twin studies which have shown that the heritability of $\mathrm{AD}$ in general is high (between 60 and 80\%) [3]. This latter study has also shown that age at onset (AAO) is significantly more consistent for pairs of monozygotic twins than for dizygotic twins, indicating that genetic variants also explain a substantial proportion of AAO variation across $\mathrm{AD}$ cases [3]. While these observations highlight the importance of genetic factors in the risk for developing $\mathrm{AD}$, at present, only the $\varepsilon 4$ allele of the apolipoprotein $\mathrm{E}(A P O E)$ gene has been unequivocally identified as a major determinant for the non-Mendelian forms of AD [4-6]. In addition, currently more than two dozen loci show significant risk effects in meta-analyses synthesizing the available data from all published studies in the field. (http://www.alzgene.org) [7].

We recently reported that the gene coding for the newly characterized calcium homeostasis modulator 1 (CALHM1) channel may be a potential genetic risk factor for non-Mendelian forms of AD. The less common allele (L) of a non-synonymous polymorphism (P86L or rs2986017) within this gene was found to be associated with an increased risk for developing AD. Further it was shown that the underlying amino-acid substitution from proline to leucine leads to a loss of $\mathrm{Ca}^{2+}$ permeability, modulation of $\mathrm{A} \beta \mathrm{PP}$ metabolism and, ultimately, to an increase in $\mathrm{A} \beta$ peptide secretion [8]. However, although CALHM1's biological properties make it a plausible AD risk factor [8,9], most of the currently published follow-up studies in Caucasian populations were unable to confirm the association between the P86L polymorphism and the risk of developing AD [10-14], with the exception of one report [15]. Despite this contradictory data using affection status as phenotype, three studies, in addition to the original report, showed association between an earlier AAO and homozygosity of the L allele and a marker in the CALHM1 vicinity $[11,15,16]$.

In this study, we assessed the question whether or not $C A L H M 1$ is a genetic susceptibility factor for nonMendelian AD, we genotyped a total of 9,662 individuals (2,249 cases and 7,413 controls) not previously tested for CALHMI and performed a meta-analysis synthesizing these data with previously published genotypes in a total sample of 7,873AD cases and 13,274 controls of Caucasian origin.

\section{MATERIALS AND METHODS}

Case-control samples were obtained from centers in Belgium (1 study) [12,17], Finland (1 study) [10], France (3 studies) [8,18], Italy (10 studies) [14,17], Spain (4 studies) $[15,17]$, Sweden (1 studies) [10], the UK (1 study) [9], and the USA (3 studies) [8,11,13]. The main characteristics of the different populations in each country are described in Supplementary Table 3 (available online: Supplementary data available online: http://www.j-alz.com/issues/22/vol22-1.html \#supplementarydata04). Clinical diagnoses of probable AD were all established according to the DSM-III-R and NINCDS-ADRDA criteria [19]. Controls were defined as subjects not meeting the DMS-III-R dementia criteria and with intact cognitive functions (mini mental status examination score $>25$ ). Written informed consent to participation was provided by all subjects or, in cases of substantial cognitive impairment, a caregiver, legal guardian or other proxy. The study protocols for all populations were reviewed and approved by the appropriate institutional review boards in each country. Depending on the center, a broad range panel of technologies were used to genotype the rs2986017 SNP [8, 10-15].

Univariate analysis was performed using Pearson's $\chi^{2}$ test. Review Manager software release 5.0 (http:// www.cc-ims.net/RevMan/) was used to estimate the overall effect (random effect odds ratio). For multivariate analysis, SAS software release 9.1 was used (SAS Institute, Cary, NC) and inter-population homo- 
Table 1

Association between the CALHM1 P86L polymorphism and age at onset (in years \pm SD) for all AD cases and for $\varepsilon 4$ or non- $\varepsilon 4$ AD cases

\begin{tabular}{|c|c|c|c|c|c|c|}
\hline & \multicolumn{2}{|c|}{ Whole } & \multicolumn{2}{|c|}{$\varepsilon 3$ bearers } & \multicolumn{2}{|c|}{ Non $\varepsilon 4$ bearers } \\
\hline & $\mathrm{n}$ & age at onset & $\mathrm{n}$ & age at onset & $\mathrm{n}$ & age at onset \\
\hline GG & 3658 & $73.0 \pm 8.9$ & 1969 & $72.0 \pm 7.9$ & 1673 & $74.2 \pm 9.8$ \\
\hline AG & 2761 & $73.1 \pm 8.9$ & 1473 & $71.9 \pm 8.3$ & 1277 & $74.4 \pm 9.5$ \\
\hline $\mathrm{AA}$ & 588 & $71.8 \pm 8.9$ & 316 & $70.2 \pm 8.2$ & 271 & $73.6 \pm 9.3$ \\
\hline $\mathrm{p}^{1}$ & & 0.004 & & $2 \times 10^{-4}$ & & 0.78 \\
\hline$\Delta(\mathrm{AA} \text { versus } \mathrm{AG}+\mathrm{GG})^{2}$ & & -1.2 & & -1.8 & & -0.7 \\
\hline $\mathrm{p}^{3}$ & & $8 \times 10^{-4}$ & & $4 \times 10^{-5}$ & & 0.54 \\
\hline
\end{tabular}

${ }^{1}$ mixed model adjusted for gender and using center as a random variable

${ }^{2} \Delta$, the difference in AAO between LL and PL + PP carriers (in years).

${ }^{3}$ the difference in AAO between LL and PL + PP carriers, using a mixed model adjusted for gender and with center as a random variable.

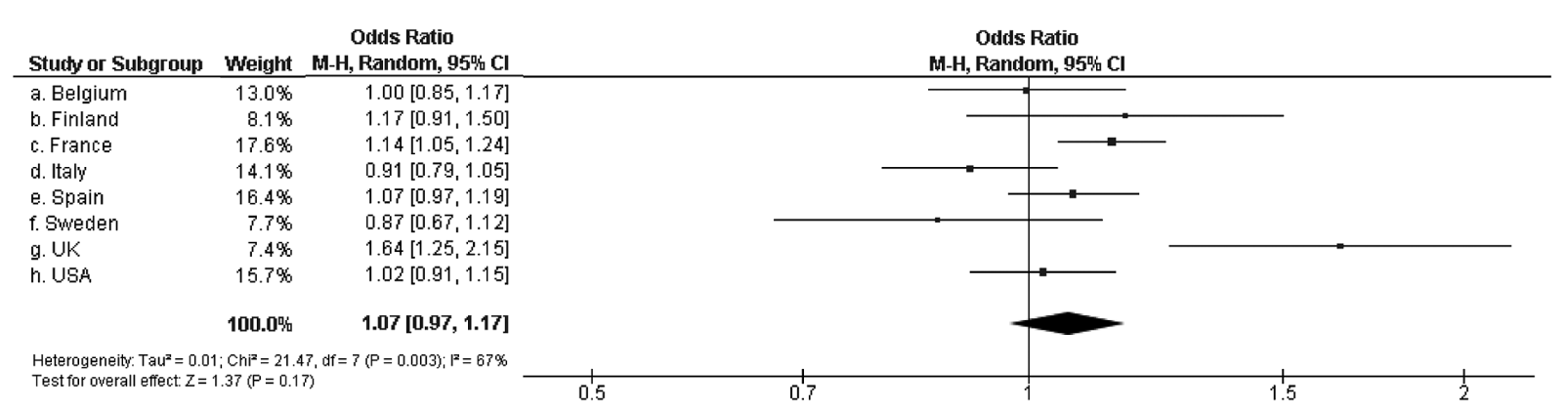

Fig. 1. Association between the P86L L allele and the risk of developing AD in the different case-control studies, according to the country of origin.

geneity between was tested using Breslow-Day computation [20]. The association of the P86L polymorphism with the risk of developing AD was assessed by a multiple logistic regression model adjusted for age, gender, APOE status and center or country (see Supplementary Table 3 for description of AAO per country). The association between the P86L polymorphism and AAO was assessed using a mixed model adjusted for gender and using the center as a random variable. Similar results were obtained when using the country as a random variable (data not shown). The presence or absence of an interaction between APOE status and the P86L polymorphism was systematically assessed in all logistic regression or mixed models.

\section{RESULTS}

Upon combining all available case-control genotype data for the P86L SNP in allele-based effects metaanalyses, we observed that the population-specific ORs showed significant evidence for heterogeneity across datasets $(p=0.003)$. We thus calculated the summary OR using a random-effects model, where the overall P86L association appeared to be not significant $(\mathrm{OR}=1.07 ; 95 \%$ confidence interval $(\mathrm{CI})$ [0.97-1.17]; $p=0.17$; Fig. 1). Upon exclusion of the five initial case-control datasets (all part of the initial, positive study) [8], the heterogeneity across population-specific ORs was substantially reduced $(p=0.29)$, but neither meta-analysis showed significant results $(\mathrm{OR}=1.01$; 95\% CI [0.95-1.08]; $p=0.76$ ).

As we had access to subject-level genotype and phenotype data for all samples, we also tested for association between P86L and AD risk by pooling data across studies and adjusting for age, gender, APOE $\varepsilon 4$ status, and center using an additive logistic regression model. This model is equivalent to the allelic association approach when the conditions for Hardy-Weinberg equilibrium are met [21], which was true for the combined sample (Supplementary Table 1). In this model, the L allele of the P86L polymorphism was weakly associated with $\mathrm{AD}(\mathrm{OR}=1.09 ; 95 \% \mathrm{CI}[1.03-1.15] ; p=$ 0.002 ). However, this association was mainly driven by the initial case-control datasets of the original report, and was no longer significant after exclusion of these samples (OR $=1.02 ; 95 \%$ CI [0.95-1.08], adjusted for age, gender, APOE status, and center; $p=0.66$ ). 
Table 2

Association between the $A P O E \varepsilon 4$ allele alone and in combination with the $\mathrm{P} 86 \mathrm{~L}$ polymorphism with age at onset (in years \pm SD)

\begin{tabular}{lccccrc}
\hline APOE & $\mathrm{n}$ & Age at onset $^{1}$ & APOE & rs2986017 & \multicolumn{1}{c}{ n } & Age at onset $^{2}$ \\
\hline$\varepsilon 4-/ \varepsilon 4-$ & 3223 & $74.2 \pm 9.6$ & $\varepsilon 4-/ \varepsilon 4-$ & AG+GG & 2952 & $74.3 \pm 9.7$ \\
& & & & AA & 271 & $73.6 \pm 9.3$ \\
$\varepsilon 4-/ \varepsilon 4+$ & \multirow{2}{*}{3027} & $72.5 \pm 8.1$ & $\varepsilon 4-/ \varepsilon 4+$ & AG+GG & 2774 & $72.6 \pm 8.1$ \\
& & & & AA & 253 & $70.9 \pm 8.3$ \\
$\varepsilon 4+/ \varepsilon 4+$ & \multirow{2}{*}{736} & \multirow{2}{*}{$68.4 \pm 7.5$} & $\varepsilon 4+/ \varepsilon 4+$ & AG+GG & 671 & $69.0 \pm 7.5$ \\
& & & & AA & 65 & $67.2 \pm 7.0$ \\
\hline
\end{tabular}

${ }^{1} p=1.1 \times 10^{-31}$ (mixed model adjusted for gender and using center as a random variable).

${ }^{2} p=2.6 \times 10^{-31}$ (mixed model adjusted for gender and using center as a random variable).

Finally, we assessed the association of the P86L polymorphism with AAO using a mixed model with center of origin as a random variable. As previously reported $[8,11,15]$, patients bearing the LL genotype displayed an earlier AAO than carriers of the LP and PP genotype $(71.8 \pm 8.9$ vs. $73.0 \pm 8.9$ years of age, respectively; $p=8 \times 10^{-4}$; Table 1 and supplementary Table 2). This association was still observed after exclusion of the initial samples $(73.2 \pm 8.2$ vs. 74.3 \pm 8.2 years of age, respectively; $\mathrm{p}=0.001)$. Following the detection of an interaction between the P86L, $\mathrm{APOE} \varepsilon 2 / \varepsilon 3 / \varepsilon 4$ polymorphisms and AAO $(p=0.04)$, we stratified the data according to $A P O E$ status and observed that the association of the LL genotype with AAO was the strongest in $\varepsilon 4$ carriers $(70.2 \pm 8.5$ vs. $72.0 \pm 8.2$ years; $p=4 \times 10^{-5}$ (Table 1 and Supplementary Table 2). Again, this association was still observed after exclusion of the initial samples $(71.9 \pm 7.4$ vs. $73.2 \pm 7.5$ years of age, respectively; $p=0.002$ ).

When taking into account the well characterized $A P O E \varepsilon 4$ allele dose effect on $\mathrm{AAO}$, we observed that the P86L LL genotype was systematically associated with a decrease in $\mathrm{AAO}$ in $\varepsilon 3 / \varepsilon 4$ and $\varepsilon 4 / \varepsilon 4$ carriers (Table 2). Comparison of likelihood ratio between a mixed model including only APOE genotype and a mixed model including both APOE and CALHM1 genotypes indicated that addition of the CALHM1 P86L polymorphism was more informative to explain the AAO variability than the APOE $\varepsilon 4$ allele alone $(p=1 \times$ $\left.10^{-10}\right)$.

\section{DISCUSSION}

Using both novel and previously published genotype data, we performed meta-analyses of 7,873 AD cases and 13,274 controls from 24 centers assessing the potential association between the P86L polymorphism in CALHM1 and risk for AD, but were unable to replicate the initial findings. The discrepancy of risk effects between the independent follow-up data and the data first published by Dreses-Werringloer et al. [8], may indicates a false-positive finding in the initial report, a situation commonly observed in genetically complex diseases and referred to as "proteus phenomenon" or to as the "winner's curse phenomenon" [22]. In addition to chance variation and technical artifacts, this may be caused by population substructure across cases and controls included in the affected association studies. Indeed, this type of difference can lead to spurious associations between diseases and genetic markers [23-26], particularly when low increases in risk are involved [27]. This observation may be particularly relevant for the P86L L allele, since its frequency appears to be highly variable (even ranging from 20 to $31 \%$ for Caucasian populations) and its association with $\mathrm{AD}$ risk was categorized as moderate in the initial report [8].

However, even though our meta-analysis results rather unequivocally refute the initial findings suggesting that CALHM1 is a genetic risk factor for $\mathrm{AD}$, the present work suggests that the CALHM1 P86L polymorphism could modulate AAO and more specifically the $A P O E \varepsilon 4$ allele's dose effect on this phenotype. Interestingly, several studies have shown that AAO in AD is highly heritable [28,29], and (in addition to the strong association of the $\varepsilon 4$ allele with AAO) it has been suggested that genes such as GTS1 or GTS2 may have a specific effects on AAO without necessarily modifying the risk for developing $\mathrm{AD}$ [30-32], although these findings have not been independently replicated to date. In this context, it is worth noting that AAO data are difficult to acquire reliably reducing the power of such analyses. Although the large overall sample size analyzed in the present study should help to decrease the likelihood of a false-positive outcome, additional genetic studies will be required to further characterize the association between the P86L polymorphism and $\mathrm{AAO}$ in $\varepsilon 4$-carriers. However, it appeared that the association of the P86L polymorphism with AAO was still 
observed after exclusion of the initial samples, this supporting a real impact of CALHMI on disease progression. It is also worth noting that factors affecting AAO tends to be spuriously associated with disease susceptibility (and the younger the cases the stronger this artifact association may be) and this confounding effect may explain in part positive results in cross-sectional studies [33].

Furthermore, it would be of particular interest to extend the association analyses to non-Caucasian populations, such as those of South-East Asian (for which conflicting results have already been reported [34-36]), or African descent. However, since the P86L L allele frequency is lower in Asian populations than Caucasian populations, particularly large sample sizes will be needed to detect significant risk or AAO effects.

Given that the P86L L allele has been associated with an increase in $\mathrm{A} \beta$ production in vitro [8], confirmation of this association with AAO may indicate that a variation in $\mathrm{A} \beta$ production can modulate $\mathrm{AD}$ progression without increasing the AD risk. Interestingly, biological evidence suggests that both the $A P O E$ gene and the genetic determinants characterized in two recent genome-wide association studies (GWASs) in AD may be primarily involved in $\mathrm{A} \beta$ peptide clearance $[17,37]$. Combination of these genetic results and physiopathological data may thus indicate that whereas familial, early-onset forms of AD are mainly linked to genes that are involved in $\mathrm{A} \beta$ overproduction, genetic variants of APOE and the GWAS-defined loci may influence susceptibility to late-onset forms of the disease via a role in $\mathrm{A} \beta$ clearance [38]. In this context, we could hypothesize that the moderate over-production of $\mathrm{A} \beta$ peptides associated with the P86L L allele only modifies the AD process when there is a failure in $\mathrm{A} \beta$ clearance $-\mathrm{a}$ failure that is likely to be particularly exacerbated in $\varepsilon 4$ carriers.

In conclusion, the present meta-analysis does not support the notion that CALHM1 is a genetic risk factor for $\mathrm{AD}$. However, we found a significant association between the P86L L-allele and earlier onset for AD, particularly in carriers of the APOE $\varepsilon 4$-allele. Therefore, further studies are warranted aimed at investigating whether or not genetic variation at CALHM1 may modify some of the pathophysiological processes involving $\mathrm{Ca}^{2+}$ homeostasis and leading to AD [39-41], in particular in carriers of the APOE $\varepsilon 4$ allele.

\section{ACKOWLEDGMENTS}

This work was made possible by the generous participation of the control subjects, the patients, and their families. We thank Dr. Anne Boland (CNG) for her technical help in preparing the DNA samples for analyses. This work was supported by the National Foundation for Alzheimer's disease and related disorders, the Institut Pasteur de Lille and the Centre National de Génotypage. The Three-City Study was performed as part of a collaboration between the Institut National de la Santé et de la Recherche Médicale (Inserm), the Victor Segalen Bordeaux II University and Sanofi-Synthélabo. The Fondation pour la Recherche Médicale funded the preparation and initiation of the study. The 3C Study was also funded by the Caisse Nationale d'assurance des Maladie des Travailleurs Salariés, Direction Générale de la Santé, MGEN, Institut de la Longévité,Agence Française de Sécurité Sanitaire des Produits de Santé, the Aquitaine and Bourgogne Regional Councils, Fondation de France and the joint French Ministry of Research/INSERM"Cohortes et collections de données biologiques" programme. Lille Génopôle received an unconditional grant from Eisai.

Belgium sample collection: the Antwerp site (CVB) was in part supported by the VIB Genetic Service Facility (http://www.vibgeneticservicefacility.be) and the Biobank of the Institute Born-Bunge; the Special Research Fund of the University of Antwerp; the Fund for Scientific Research-Flanders (FWO-V); the Foundation for Alzheimer Research (SAOFRMA), the Interuniversity Attraction Poles (IAP) program P6/43 of the Belgian Federal Science Policy Office; Belgium; K.S. is a postdoctoral fellow and K.B. a PhD fellow of the FWO-V.

Finish sample collection: Financial support for this project was provided by the Health Research Council of the Academy of Finland, EVO grant 5772708 of Kuopio University Hospital, and the Nordic Centre of Excellence in Neurodegeneration.

Italian sample collections: the Bologna site (FL) obtained funds from the Italian Ministry of research and University as well as Carimonte Foundation. The Florence site was supported by grants from Sanpaolo 1070IT/CV2007.0548 and the Fondazione Cassa di resparmio di Pistoia e pescia (prot. 2009.0220). The Milan site was supported by grants from the "Fondazione Monzino" and the Italian Ministry of Health. We thank the expert contribution of Mr. Carmelo Romano. This work was performed in the frame of AMBISEN Center, High Technology Center for the study of the Environmental Damage of Endocrine and Nervous System, University of Pisa. We thank Dr. A. LoGerfo for the preparation of the DNA collection. The Cagliari 
site was partly supported by a grant from the Italian Ministry of Health (Progetti di Ricerca Finalizzati).

Spanish sample collection: the Madrid site (MB) was supported by grants of the Ministerio de Educación y Ciencia and the Ministerio de Sanidad y Consumo (Instituto de Salud CarlosIII), and an institutional grant of the Fundación Ramón Areces to the CBMSO. We thank I.Sastre and Dr. A Martínez-García for the preparation and control of the DNA collection, and Drs. P. Gil and P. Coria for their cooperation in the cases/controls recruitment. We are grateful to the Asociación de Familiares de Alzheimer de Madrid (AFAL) for continuous encouragement and help. The Neocodex centre thanks the staff of the Memory Clinic of Fundació ACE. Institut Català de Neurociències Aplicades (Barcelona,Spain), Ana Mauleón, Maitée Rosende-Roca, Pablo Martínez-Lage, Montserrat Alegret, Susana Ruíz and Lluís Tárraga. We are indebted to the Unidad de Demencias, Hospital Universitario Virgen de la Arrixaca (Murcia, Spain), Juan Marin, and to the Memory Unit of the Hospital Universitario La Paz-Cantoblanco (Madrid, Spain). This study has been partially funded by Fundación Alzheimur (Murcia) and the Ministerio de Educación y Ciencia (Gobierno de España)(PCT-010000-2007-18).

US sample collections. The study was partly supported by USA National Institute on Aging (NIA) grant AG030653, AG005133, AG20135, AG19757), by National Institute of Neurological Disorders and Stroke (NS31153), the Alzheimer's Association, and the Louis D. Scientific Award of the Institut de France. A subset of the participants was ascertained while Margaret A. Pericak-Vance was a faculty member at Duke University.

Authors' disclosures available online (http://www.jalz.com/disclosures/view.php?id=494).

\section{REFERENCES}

[1] Hardy J (1997) Amyloid, the presenilins and Alzheimer's disease. Trends Neurosci 20, 154-159.

[2] Campion D, Dumanchin C, Hannequin D, Dubois B, Belliard S, Puel M, Thomas-Anterion C, Michon A, Martin C, Charbonnier F, Raux G, Camuzat A, Penet C, Mesnage V, Martinez M, Clerget-Darpoux F, Brice A, Frebourg T (1999) Early-onset autosomal dominant Alzheimer disease: prevalence, genetic heterogeneity, and mutation spectrum. Am J Hum Genet $\mathbf{6 5}$, 664-670.

[3] Gatz M, Reynolds CA, Fratiglioni L, Johansson B, Mortimer JA, Berg S, Fiske A, Pedersen NL (2006) Role of genes and environments for explaining Alzheimer disease. Arch Gen Psychiatry 63, 168-174.
[4] Farrer LA, Cupples LA, Haines JL, Hyman B, Kukull WA, Mayeux R, Myers RH, Pericak-Vance MA, Risch N, van Duijn CM (1997) Effects of age, sex, and ethnicity on the association between apolipoprotein E genotype and Alzheimer disease. A meta-analysis. APOE and Alzheimer Disease Meta Analysis Consortium. JAMA 278, 1349-1356.

[5] Bertram L, Tanzi RE (2008) Thirty years of Alzheimer's disease genetics: the implications of systematic meta-analyses. Nat Rev Neurosci 9, 768-778.

[6] Lambert J-C, Amouyel P (2007) Genetic heterogeneity of Alzheimer's disease: complexity and advances. Psychoneuroendocrinology 32, S62-70.

[7] Bertram L, McQueen MB, Mullin K, Blacker D, Tanzi RE (2007) Systematic meta-analyses of Alzheimer disease genetic association studies: the AlzGene database. Nat Genet 39, 1723.

[8] Dreses-Werringloer U, Lambert JC, Vingtdeux V, Zhao H, Vais H, Siebert A, Jain A, Koppel J, Rovelet-Lecrux A, Hannequin D, Pasquier F, Galimberti D, Scarpini E, Mann D, Lendon C, Campion D, Amouyel P, Davies P, Foskett JK, Campagne F, Marambaud P (2008) A polymorphism in CALHM1 influences $\mathrm{Ca} 2+$ homeostasis, Abeta levels, and Alzheimer's disease risk. Cell 133, 1149-1161.

[9] Moreno-Ortega AJ, Ruiz-Nuño A, García AG, Cano-Abad MF (2010) Mitochondria sense with different kinetics the calcium entering into HeLa cells through calcium channels CALHM1 and mutated P86L-CALHM1. Biochem Biophys Res Commun 391, 722-6.

[10] Bertram L, Schjeide BM, Hooli B, Mullin K, Hiltunen M, Soininen H, Ingelsson M, Lannfelt L, Blacker D, Tanzi RE (2008) No association between CALHM1 and Alzheimer's disease risk. Cell 135, 993-994.

[11] Minster RL, Demirci FY, DeKosky ST, Kamboh MI (2009) No association between CALHM1 variation and risk of Alzheimer disease. Hum Mutat 30, E566-569.

[12] Sleegers K, Brouwers N, Bettens K, Engelborghs S, van Miegroet H, De Deyn PP, Van Broeckhoven C (2009) No association between CALHM1 and risk for Alzheimer dementia in a Belgian population. Hum Mutat 30, E570-574.

[13] Beecham GW, Schnetz-Boutaud N, Haines JL, Pericak-Vance MA (2009) CALHM1 polymorphism is not associated with late-onset Alzheimer disease. Ann Hum Genet 73, 379-81.

[14] Nacmias B, Tedde A, Bagnoli S, Lucenteforte E, Cellini E, Piaceri I, Guarnieri BM, Bessi V, Bracco L, Sorbi S Lack of implication for CALHM1 P86L common variation in Italian patients with early and late-onset Alzheimer's disease. $J$ Alzheimers Dis 20, 37-41.

[15] Boada M, Antúnez C, López-Arrieta J, Galán JJ, Morón FJ, Hernández I, Marín J, Martínez-Lage P, Alegret M, Carrasco JM, Moreno C, Real LM, González-Pérez A, Tárraga L, Ruiz A. (2010) CALHM1 P86L polymorphism is associated with late-onset Alzheimer's disease in a recessive model. $J$ Alzheimers Dis 20, 247-251.

[16] Li H, Wetten S, Li L, St Jean PL, Upmanyu R, Surh L, Hosford D, Barnes MR, Briley JD, Borrie M, Coletta N, Delisle R, Dhalla D, Ehm MG, Feldman HH, Fornazzari L, Gauthier S, Goodgame N, Guzman D, Hammond S, Hollingworth P, Hsiung GY, Johnson J, Kelly DD, Keren R, Kertesz A, King KS, Lovestone S, Loy-English I, Matthews PM, Owen MJ, Plumpton M, Pryse-Phillips W, Prinjha RK, Richardson JC, Saunders A, Slater AJ, St George-Hyslop PH, Stinnett SW, Swartz JE, Taylor RL, Wherrett J, Williams J, Yarnall DP, Gibson RA, Irizarry MC, Middleton LT, Roses AD (2008) Can- 
didate single-nucleotide polymorphisms from a genomewide association study of Alzheimer disease. Arch Neurol 65, 45-53.

[17] Lambert JC, Heath S, Even G, Campion D, Sleegers K, Hiltunen M, Combarros O, Zelenika D, Bullido MJ, Tavernier B, Letenneur L, Bettens K, Berr C, Pasquier F, Fiévet $\mathrm{N}$, Barberger-Gateau P, Engelborghs S, De Deyn P, Mateo I, Franck A, Helisalmi S, Porcellini E, Hanon O; European Alzheimer's Disease Initiative Investigators, de Pancorbo MM, Lendon C, Dufouil C, Jaillard C, Leveillard T, Alvarez V, Bosco $\mathrm{P}$, Mancuso $\mathrm{M}$, Panza $\mathrm{F}$, Nacmias $\mathrm{B}$, Bossù $\mathrm{P}$ Piccardi P, Annoni G, Seripa D, Galimberti D, Hannequin D, Licastro F, Soininen H, Ritchie K, Blanché H, Dartigues JF, Tzourio C, Gut I, Van Broeckhoven C, Alpérovitch A, Lathrop M, Amouyel P (2009) Genome wide association indentifies variants at CLU and CR1 associated with Alzheimer's disease. Nat Genet 41, 1094-1099.

[18] Chapuis J, Hot D, Hansmannel F, Kerdraon O, Ferreira S, Hubans C, Maurage CA, Huot L, Bensemain F, Laumet G, Ayral AM, Fievet N, Hauw JJ, DeKosky ST, Lemoine Y, Iwatsubo T, Wavrant-Devrièze F, Dartigues JF, Tzourio C, Buée L, Pasquier F, Berr C, Mann D, Lendon C, Alpérovitch A, Kamboh MI, Amouyel P, Lambert JC (2009) Transcriptomic and genetic studies identify IL-33 as a candidate gene for Alzheimer's disease. Mol Psychiatry 14, 1004-1016.

[19] McKhann G, Drachman D, Folstein M, Katzman R, Price D, Stadlan EM (1984) Clinical diagnosis of Alzheimer's disease: report of the NINCDS-ADRDA Work Group under the auspices of Department of Health and Human Services Task Force on Alzheimer's disease. Neurology 34, 939-944.

[20] Breslow NE, Day NE, Halvorsen KT, Prentice RL, Sabai C (1978) Estimation of multiple relative risk functions in matched case-control studies. Am J Epidemiol 108, 299-307.

[21] Schaid DJ, Jacobsen SJ (1999) Biased tests of association: comparisons of allele frequencies when departing from HardyWeinberg proportions. Am J Epidemiol 149, 706-711.

[22] Kraft P (2008) Curses-winner's and otherwise-in genetic epidemiology. Epidemiology 19, 649-651.

[23] Freedman ML, Reich D, Penney KL, McDonald GJ, Mignault AA, Patterson N, Gabriel SB, Topol EJ, Smoller JW, Pato CN, Pato MT, Petryshen TL, Kolonel LN, Lander ES, Sklar P, Henderson B, Hirschhorn JN, Altshuler D (2004) Assessing the impact of population stratification on genetic association studies. Nat Genet 36, 388-393.

[24] Marchini J, Cardon LR, Phillips MS, Donnelly P (2004) The effects of human population structure on large genetic association studies. Nat Genet 36, 512-517.

[25] Clayton DG, Walker NM, Smyth DJ, Pask R, Cooper JD, Maier LM, Smink LJ, Lam AC, Ovington NR, Stevens HE, Nutland S, Howson JM, Faham M, Moorhead M, Jones HB, Falkowski M, Hardenbol P, Willis TD, Todd JA (2005) Population structure, differential bias and genomic control in a large-scale, case-control association study. Nat Genet 37, 1243-1246.

[26] Heath SC, Gut IG, Brennan P, McKay JD, Bencko V, Fabianova E, Foretova L, Georges M, Janout V, Kabesch M, Krokan HE, Elvestad MB, Lissowska J, Mates D, Rudnai P, Skorpen F, Schreiber S, Soria JM, Syvänen AC, Meneton P, Herçberg S, Galan P, Szeszenia-Dabrowska N, Zaridze D, Génin E, Cardon LR, Lathrop M (2008) Investigation of the fine structure of European populations with applications to disease association studies. Eur J Hum Genet 16, 1413-1429.

[27] Ioannidis JP, Boffetta P, Little J, O'Brien TR, Uitterlinden AG, Vineis P, Balding DJ, Chokkalingam A, Dolan SM, Flanders WD, Higgins JP, McCarthy MI, McDermott DH, Page GP, Rebbeck TR, Seminara D, Khoury MJ (2008) Assessment of cumulative evidence on genetic associations: interim guidelines. Int J Epidemiol 37, 120-132.

[28] Daw EW, Heath SC, Wijsman EM (1999) Multipoint oligogenic analysis of age-at-onset data with applications to Alzheimer disease pedigrees. Am J Hum Genet 64, 839-851.

[29] Li YJ, Scott WK, Hedges DJ, Zhang F, Gaskell PC, Nance MA, Watts RL, Hubble JP, Koller WC, Pahwa R, Stern MB, Hiner BC, Jankovic J, Allen FA Jr, Goetz CG, Mastaglia F, Stajich JM, Gibson RA, Middleton LT, Saunders AM, Scott BL, Small GW, Nicodemus KK, Reed AD, Schmechel DE, Welsh-Bohmer KA, Conneally PM, Roses AD, Gilbert JR, Vance JM, Haines JL, Pericak-Vance MA (2002) Age at onset in two common neurodegenerative diseases is genetically controlled. Am J Hum Genet 70, 985-993.

[30] Li YJ, Oliveira SA, Xu P, Martin ER, Stenger JE, Scherzer CR, Hauser MA, Scott WK, Small GW, Nance MA, Watts RL, Hubble JP, Koller WC, Pahwa R, Stern MB, Hiner BC, Jankovic J, Goetz CG, Mastaglia F, Middleton LT, Roses AD, Saunders AM, Schmechel DE, Gullans SR, Haines JL, Gilbert JR, Vance JM, Pericak-Vance MA, Hulette C, Welsh-Bohmer KA (2003) Glutathione S-transferase omega-1 modifies ageat-onset of Alzheimer disease and Parkinson disease. Hum Mol Genet 12, 3259-3267.

[31] Kölsch H, Linnebank M, Lütjohann D, Jessen F, Wüllner U, Harbrecht U, Thelen KM, Kreis M, Hentschel F, Schulz A, von Bergmann K, Maier W, Heun R (2004) Polymorphisms in glutathione S-transferase omega-1 and AD, vascular dementia, and stroke. Neurology 63, 2255-2260.

[32] Li YJ, Scott WK, Zhang L, Lin PI, Oliveira SA, Skelly T, Doraiswamy MP, Welsh-Bohmer KA, Martin ER, Haines JL, Pericak-Vance MA, Vance JM (2006) Revealing the role of glutathione S-transferase omega in age-at-onset of Alzheimer and Parkinson diseases. Neurobiol Aging 27, 1087-1093.

[33] Dartigues JF, Letenneur L (2000) Genetic epidemiology of Alzheimer's disease. Curr Opin Neurol 13, 385-9.

[34] Tan EK, Ho P, Cheng SY, Yih Y, Li HH, Fook-Chong S, Lee WL, Zhao Y (2009) CALHM1 variant is not associated with Alzheimer's disease among Asians. Neurobiol Aging, in press.

[35] Inoue K, Tanaka N, Yamashita F, Sawano Y, Asada T, Goto YI (2010) The P86L common allele of CALHM1 does not influence risk for Alzheimer disease in Japanese cohorts. Am J Med Genet 153, 532-535.

[36] Cui PJ, Zheng L, Cao L, Wang Y, Deng YL, Wang G, Xu W, Tang HD, Ma JF, Zhang T, Ding JQ, Cheng Q, Chen SD (2010) CALHM1 P86L polymorphism is a risk factor for Alzheimer's disease in the Chinese population. J Alzheimers Dis 19, 31-35.

[37] Harold D, Abraham R, Hollingworth P, Sims R, Gerrish A, Hamshere ML, Pahwa JS, Moskvina V, Dowzell K, Williams A, Jones N, Thomas C, Stretton A, Morgan AR, Lovestone S, Powell J, Proitsi P, Lupton MK, Brayne C, Rubinsztein DC, Gill M, Lawlor B, Lynch A, Morgan K, Brown KS, Passmore PA, Craig D, McGuinness B, Todd S, Holmes C, Mann D, Smith AD, Love S, Kehoe PG, Hardy J, Mead S, Fox N, Rossor M, Collinge J, Maier W, Jessen F, Schürmann B, van den Bussche H, Heuser I, Kornhuber J, Wiltfang J, Dichgans M, Frölich L, Hampel H, Hüll M, Rujescu D, Goate AM, Kauwe JS, Cruchaga C, Nowotny P, Morris JC, Mayo K, Sleegers K, Bettens K, Engelborghs S, De Deyn PP, Van Broeckhoven C, Livingston G, Bass NJ, Gurling H, McQuillin A, Gwilliam R, Deloukas P, Al-Chalabi A, Shaw CE, Tsolaki M, Singleton $\mathrm{AB}$, Guerreiro R, Mühleisen TW, Nöthen MM, Moebus S, Jöckel KH, Klopp N, Wichmann HE, Carrasquillo MM, Pankratz VS, Younkin SG, Holmans PA, O'Donovan M, Owen MJ, Williams J (2009) Genome wide association indentifies 
variants at CLU and PICALM associated with Alzheimer's disease. Nat Genet 41, 1088-1093.

[38] Holtzman DM (2004) In vivo effects of ApoE and clusterin on amyloid-beta metabolism and neuropathology. J Mol Neurosci 23, 247-254.

[39] Small DH (2009) Dysregulation of calcium homeostasis in Alzheimer's disease. Neurochem Res 34, 1824-1829.

[40] Marambaud P, Dreses-Werringloer U, Vingtdeux V (2009)
Calcium signaling in neurodegeneration. Mol Neurodegener 4, 20.

[41] Lambert JC, Grenier-Boley B, Chouraki V, Heath S, Zelenika D, Fievet N, Hannequin D, Pasquier F, Hanon O, Brice A, Epelbaum J, Berr C, Dartigues JF, Tzourio C, Campion D, Lathrop M, Amouyel P (2010) Implication of the immune system in Alzheimer's disease: evidence from Genome-wide pathway analysis. J Alzheimers Dis 20, 1107-18. 